\title{
The Simulation of Fluid Flow and Heat Transfer in a Fluidized Bed Spray Dryer with a Vortex Generator $30^{\circ}$ toward the $\mathrm{Y}$ Axis
}

\author{
Pratomo Setyadi ${ }^{1 *}$, Nugroho Gama Yoga ${ }^{1}$, Muhammad Rizqi ${ }^{1}$, Fajar Nur Amsir ${ }^{1}$
}

Mechanical Engineering Department Universitas Negeri Jakarta Jalan Rawamangun Muka 13220

*Corresponding author. Email: psetyadi@unj.ac.id

\begin{abstract}
The Fluidized Bed Spray Dryer is a spray drying machine that works by treating the milk solution particles as a fluid, which flows in a 2-phase stream at different temperatures. The purpose of this research are to see the vortex phenomenon that formed and the effect in heat transfer process, later compared with temperature distribution during experiment. In this simulation, the Spray Dryer has a Vortex Generator with a specification of $30^{\circ}$ to the Y axis and opposing each other (Cross Flow). This simulation was carried out at 5 different temperatures with air flow velocity of $26 \mathrm{~m} / \mathrm{s}$, inlet flow rate of $5.83 \times 10-4 \mathrm{~kg} / \mathrm{s}$, injector diameter of $0.1 \mathrm{~mm}$, the injector spray angle width of $45^{\circ}$ and the droplet size of $5 \mu \mathrm{m}$. The injector is placed in 3 conditions. The first is located under the vortex generator hole in as far as $4 \mathrm{~cm}$ and the second is parallel to exhaust of vortex generator, and third is above the vortex generator hole in as far as $4 \mathrm{~cm}$. The simulation results from this study are visualized in the form of contour plots on the distribution of heat transfer, heat transfer coefficient and turbulence intensity, as well as path lines of air flow velocity. Thus, from the simulation results, it was found that the vortex occurred in the first silo, with a turbulence intensity value of $174 \%$, making the heat distribution in the first silo evenly distributed. The highest convection coefficient value is achieved at injector position $1,4 \mathrm{~mm}$ below the air duct tip, the value is $58.8 \mathrm{~W} / \mathrm{m}^{2} \mathrm{~K}$.
\end{abstract}

\section{Keywords: Bed Spray, Vortex Generator, Fluid flow, Heat Transfer}

\section{INTRODUCTION}

One of the methods used to improve product quality is by means of the drying process. The results of the drying process are granular (clumps), and powder. One of the methods used in the drying process is to use a spray dryer. Some types of drying are able to improve the quality of dried food or medicinal products. However, some are not efficient in terms of energy use due to limited sources of fossil fuels, unpredictable world fuel prices, high industrialization, and rising global carbon emissions and changes in world climate. Therefore, the need for an efficient and environmentally friendly drying system becomes important in the field of drying technology [4]. Despite the high and widespread use of spray dryers, there are still many things to be developed from each process simulation and research based on the findings of the problems that occur. One of the big problems faced by Spray dryer designers and operators is the complexity of the spray/air mixing process in the Spray dryer chamber, where the airflow pattern present in the spray dryer is considered as one of the main factors affecting the Spray dryer particle output such as moisture content, size distribution, and bulk density[5]. The use of a vortex generator is intended to increase the heat transfer coefficient [6]. And, another problem that often arises in presence of particle deposits on the walls and product agglomeration [7]. With the presence of vortex generator, we expected that the heat transfers will be better and rising the efficiency of energy. The main question is what kind of vortex generator that can be applied on spray dryer? This research will give contribution to spray drying development.

Spray dryer has a working principle by spraying liquid through an atomizer. The liquid that has gone through the atomization process in the form of fine grains is then passed through a stream of hot air in a closed system 
(usually a tube). Therefore, the water in the granules evaporates very quickly leaving the solid content in the granules into a homogeneous powder form, the water content is very low and the nutritional quality is very well maintained. The results of the Spray dryer product depend on the thickness of the solution or material, the type of material, the drying temperature, and the velocity of the air flow. This tool is widely used in the food and beverage industry, one of which is milk [1]. Spray dryers have been used on a large scale in the food industry in the world. By using maltodextrin as an additional medium for binding and forming in spray drying. In this way, the resulting product does not change the properties of the substance dissolved with maltodextrin [2]. In general, what is called milk is cow's milk, which comes from the FH (Friesian Holstein) dairy cow, which is white with black, or black with white. Milk is naturally an emulsion of fat in water. Thus, the particle size of whole milk after heating to a temperature of $50-60{ }^{\circ} \mathrm{C}$ to deactivate the lipase enzyme is $5 \mu \mathrm{m}[3]$. The water content of milk is very high, with an average of $87.5 \%$, and it contains various important nutrients such as protein, fat, sugar, vitamins and minerals emulsified in it.

Drying is the process of reducing the water content of the material until it reaches a certain water content so that it inhibits the rate of material damage due to biological and chemical activities. The basis of the drying process is the evaporation of water from the material into the air due to the difference in water vapor content between the air and the material being dried. In order for a material to be dry, the air must have a relatively lower moisture content or humidity than the material being dried. Several parameters that affect the time needed in the drying process are the temperature of the drying air, the relative humidity of the drying air, the speed of the drying air and the moisture content of the material [8]. The following are some of the calculations used to fill in the parameters and boundary conditions.

Convection heat transfer is the process of moving a fluid with a higher temperature to a surface with a lower temperature. Fluid flows through the surface of an object that has a different temperature. The flow rate depends on the physical properties of the fluid and the type of fluid flow [9].

Explanation:

$$
\mathrm{q}_{\mathrm{conv}}=\mathrm{hA}\left(\mathrm{T}_{\mathrm{s}}-\mathrm{T}_{\infty}\right)
$$

h : Convection heat transfer coefficient $\left(\mathrm{W} / \mathrm{m}^{2} \mathrm{~K}\right)$

$\mathrm{T}_{\mathrm{s}} \quad$ : Surface temperature $(\mathrm{K})$

$\mathrm{T}_{\infty} \quad$ : Fluid temperature $(\mathrm{K})$

A : Surface

Forced convection is convection caused by the fluid on the plate surface. In forced convection, the fluid is forced to flow with the help of a device, such as a fan and a blower or air blower. The procedure for calculating the forced convection heat transfer starts from looking for the Reynolds, Prandlt, and Nusselt values in order to get the coefficient values sought as follows[9]

Reynolds number is formulated by the following equation:

$$
\operatorname{Re}=\frac{\rho U x}{\mu}=\frac{U x}{v} .
$$

Explanation:

Re : Reynold Number

$\rho \quad$ : Density of fluid $\left(\mathrm{kg} / \mathrm{m}^{3}\right)$

$\mathrm{U}$ : The velocity of the fluid flowing $(\mathrm{m} / \mathrm{s})$

$\mathrm{x}$ : The distance calculated from the leading edge to the point $\mathrm{x}(\mathrm{m})$

$\mu \quad$ : Fluid viscosity $\left(\mathrm{Ns} / \mathrm{m}^{2}\right)$

$\mathrm{v}$ : Fluid kinematic viscosity $\left(\mathrm{m}^{2} / \mathrm{det}\right)$

Nusselt number is formulated by the following equation:

$$
\frac{q_{\text {Conv }}}{q_{\text {Cond }}}=\frac{h \Delta T}{\frac{k \Delta T}{L}}=\frac{h L}{k}=N u
$$

Explanation:

$\mathrm{q}_{\text {Conv }}$ : The rate of heat transfer in convection (Watt)

$\mathrm{q}_{\text {Cond }}$ : The rate of heat transfer in conduction (Watt)

$\Delta \mathrm{T}:$ Temperature Difference $(\mathrm{K})$

$\mathrm{k}$ : Fluid Thermal Conductivity (W/m K)

$\mathrm{h}$ : Convection heat transfer coefficient (Watt $/ \mathrm{m}^{2} \mathrm{~K}$ )

$\mathrm{L} \quad$ : Wall length $(\mathrm{m})$

For turbulent flow, the following equation is used:

$$
\mathrm{Nu}=\left(0,037 \mathrm{Re}^{4 / 5}-871\right) \operatorname{Pr}{ }^{1 / 3}
$$

Convection heat transfer coefficient

$$
\mathrm{h}=\frac{N u k}{L}
$$

Explanation:

h : Heat Transfer Coefficient $\left(\mathrm{W} / \mathrm{m}^{2} \mathrm{~K}\right)$

$\mathrm{Nu}$ : Nusselt's number

\begin{tabular}{|c|c|c|c|c|c|c|}
\hline $\mathrm{T}\left({ }^{\circ} \mathrm{C}\right)$ & $\rho(\mathrm{kg} / \mathrm{m} 3)$ & $\mathrm{Cp}$ & $\begin{array}{l}\text { Thermal conductiv- } \\
\text { ity } \mathrm{K}, \mathrm{W} / \mathrm{mK}\end{array}$ & $\begin{array}{l}\text { Dynamics vis- } \\
\text { cosity } \mu, \mathrm{kg} / \mathrm{m} . \mathrm{s}\end{array}$ & $\begin{array}{c}\text { Kinematic viscos- } \\
\text { ity, } \mathrm{v} \mathrm{m}^{2} / \mathrm{s}\end{array}$ & $\begin{array}{l}\text { Prandlt } \mathrm{Nu}- \\
\text { meber, } \mathrm{Pr}\end{array}$ \\
\hline 80 & 0.9994 & 1008 & 0.02953 & $2.096 \times 10^{-5}$ & $2.097 \times 10^{5}$ & 0.7154 \\
\hline 90 & 0.9718 & 1008 & 0.03024 & $2.139 \times 10^{-5}$ & $2.201 \times 10^{5}$ & 0.7132 \\
\hline 100 & 0.9458 & 1009 & 0.03095 & $2.181 \times 10^{-5}$ & $2.306 \times 10^{5}$ & 0.7111 \\
\hline 120 & 0.8977 & 1011 & 0.03235 & $2.264 \times 10^{-5}$ & $2.522 \times 10^{5}$ & 0.7073 \\
\hline
\end{tabular}

$\mathrm{K}$ : Fluid Thermal Conductivity Fluid (W/m K)

L : Wall Length (m) $\mathrm{q}_{\mathrm{conv}}$ : Convection drying rate (Watt)

Table 1 Property Values of Dry Air at 1 Atm 
Fluidization is defined as an operation in which a solid expanse is treated like a fluid in contact with a gas or liquid. In a fluidized state, the gravitational force on the solid particles is balanced by the drag force of the fluid acting on them [10]

\section{METHODS}

CFD is a system analysis involving fluid flow, heat transfer and related phenomena such as chemical reactions through computer-based simulations[11]. The flow in a spray dryer is turbulent and two-phase (gas and droplets or gases and particles). There are usually two approaches used for two-phase flow modeling [12].First, it can be the dispersion phase as an extra liquid with the direction of flow (Eulerian approach). In the case of spray drying with the concentration of particles, it usually uses the Euler approach. The second approach, the Euler/Lagrange approach. In the solution the gas field is calculated first (Euler). If it is finished by calculating the solution of the Navier Stokes value and continuity, then the equations on the particle mesh are tracked individually (Lagrange). Through the path of the particle, the exchange of mass, energy and momentum with the continuous phase is calculated. This is an additional requirement added to the requirements of the Navier equation. After particle tracking, the airflow calculation pattern is recalculated by considering the transfer requirements. This calculation cycle is air flow followed by repeated NM particle tracking until convergence is reached. This scheme is called the Particle-in-Cell mode model[13].

The export results have no dimensional differences in the geometry of the Spray dryer when entering ANSYS. The first step is meshing. The mesh used is a tetrahedral mesh type. This type of mesh is accurate and short enough to complete simulations with complex geometric models of spray dryers [14]. Mesh consists of 90904 Nodes and 500069 Elements. This is because the ANSYS Academic License only facilitates the number of elements as many as 512000. The next one is to select the flow change over time, transient and activate the condition of acceleration of gravity against the normal force of $9.81 \mathrm{~m} / \mathrm{s} 2$. Then Select the Eularian model type for a multiphase model where the first phase is air and the second phase is a solution (a mixture of milk, maltodextrin and water). After that is to determine the viscous model of the k-epsilon 2 type with a realizable model and a standard wall function approach. Activate the Discrete Phase Model mode and select the type of injection cone. This is done because the cone type injection contains several parameters whose data has been obtained from experimental results. The simulations are carried out in 3 different conditions. Condition 1 is carried out at the in- jector position parallel to the silo surface as shown in Figure 3 , condition 2 the injector position is at the level of $0.137 \mathrm{~m}$ above the bottom surface of the silo as shown in Figure. 4 and condition 3, the injector is at the level 0.175 above the bottom surface of the silo as shown in Figure 4. The simulation is carried out by starting with a filling solution temperature of $28{ }^{\circ} \mathrm{C}$, velocity magnitude of $70.06 \mathrm{~m} / \mathrm{s}$, cone angle of $45^{\circ}$, injector diameter of $1 \times 10^{-}$ ${ }^{4} \mathrm{~m}$ or $0.1 \mathrm{~mm}$. The smallest, largest and average particle diameters are $2 \times 10-3 \mathrm{~m}, 5 \times 10^{-3} \mathrm{~m}$ and $3.5 \times 10^{-3} \mathrm{~m}$. And determine the position of the injector is (condition). The injector on the Spray dryer is installed at the level of $0,0.137 \mathrm{~m}(4 \mathrm{~cm}$ below the air outlet $)$ and $0.175 \mathrm{~m}(4 \mathrm{~cm}$ above the air outlet) to silo bottom in the first silo. The location of the injector is at the center of the silo circle. The next step is setting the boundary conditions for particles, fluids, and materials. The parameter values for fluid conditions can be seen from table 1 according to several experimental temperatures in the simulation (80 $\left.{ }^{\circ} \mathrm{C}, 90{ }^{\circ} \mathrm{C}, 100{ }^{\circ} \mathrm{C}, 110{ }^{\circ} \mathrm{C}, 120{ }^{\circ} \mathrm{C}\right)$. The value of the thermal properties of SS 304 material can be seen in table 2 . These values are then entered in the parameters of the condition of the material used (Stainless Steel 304). The next step is to enter the value of the boundary conditions at the inlet and wall. At the inlet velocity of the incoming air is $26 \mathrm{~m} / \mathrm{s}$ at each temperature of $80^{\circ} \mathrm{C}, 90^{\circ} \mathrm{C}, 100^{\circ} \mathrm{C}$, $110^{\circ} \mathrm{C}, 120^{\circ} \mathrm{C}$. and enter the value of the convection coefficient at the inlet temperature of $80^{\circ} \mathrm{C}, 90^{\circ} \mathrm{C}, 100^{\circ} \mathrm{C}$, $110^{\circ} \mathrm{C}, 120^{\circ} \mathrm{C}$, each of which is $52.25 \mathrm{~W} / \mathrm{m}^{2} \mathrm{~K} ; 51 \mathrm{~W} / \mathrm{m}^{2}$ $\mathrm{K} ; 49.77 \mathrm{~W} / \mathrm{m}^{2} \mathrm{~K} ; 48.63 \mathrm{~W} / \mathrm{m}^{2} \mathrm{~K}$; and $47.47 \mathrm{~W} / \mathrm{m}^{2} \mathrm{~K}$. Room temperature value during the experiment of $33{ }^{\circ} \mathrm{C}$ to make the simulation as if in a state of during the experiment. Next, choose a time model to choose a transient in this research simulation.

Table 2 Property of material

\begin{tabular}{|c|l|c|}
\hline \multicolumn{2}{|c|}{ Material Properties } & SS-304 \\
\hline $\begin{array}{c}\text { Mechanical } \\
\text { properties }\end{array}$ & Elastic modulus (GPa) & 193 \\
\hline & Tensile strength (MPa) & 515 \\
\hline & Yield strength (MPa) & 205 \\
\hline $\begin{array}{c}\text { Thermal } \\
\text { properties }\end{array}$ & $\begin{array}{l}\text { Thermal conductivity } \\
\text { (W/mK) }\end{array}$ & 88 \\
\hline & Spesific heat (J/kg K) & 500 \\
\hline
\end{tabular}

The solver method used in this simulation is a Pressure Based solver model. This model is used because the flow in the Spray dryer is compressible and incompress- 
ible. As well as using the Phase Coupled Simple algorithm in order to increase the time until it reaches convergence.

\subsection{Post Processor}

The last stage is to present the simulation data in the form of contour plots, and path lines.

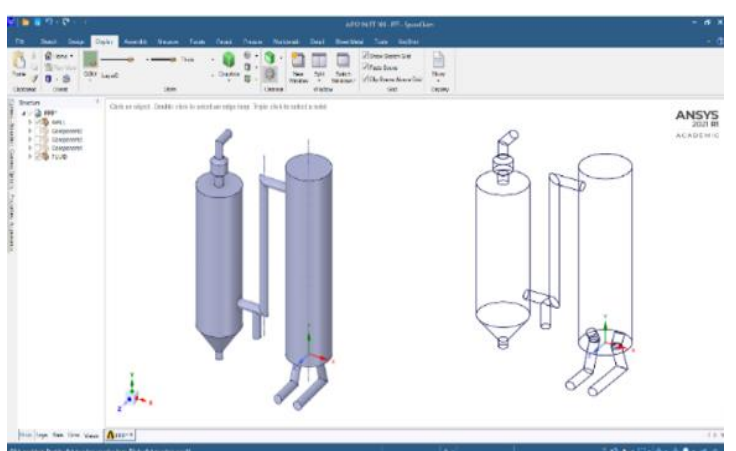

Figure 1 Geometry Export

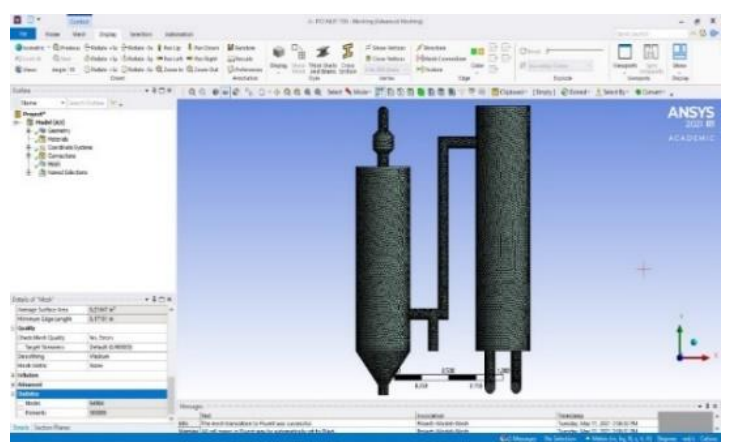

Figure 2 Meshing

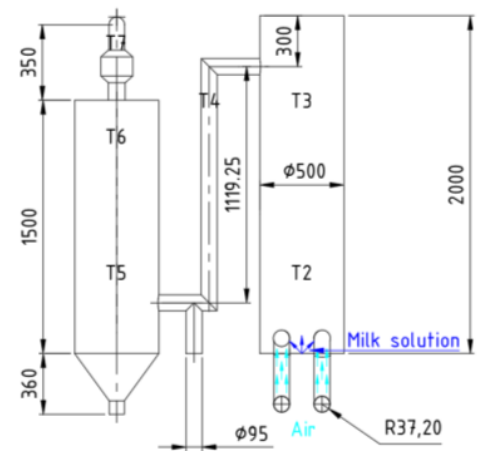

Figure 3 Spray Dryer in condition 1

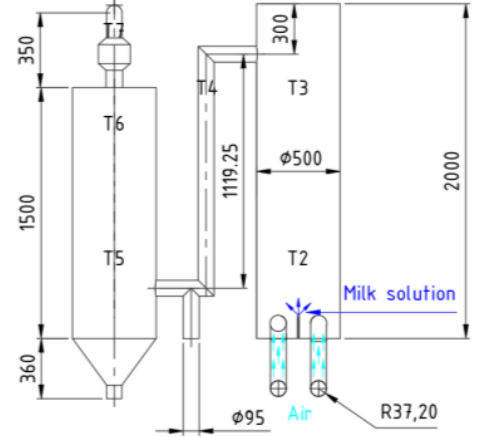

Figure 4 Spray Dryer in condition 2

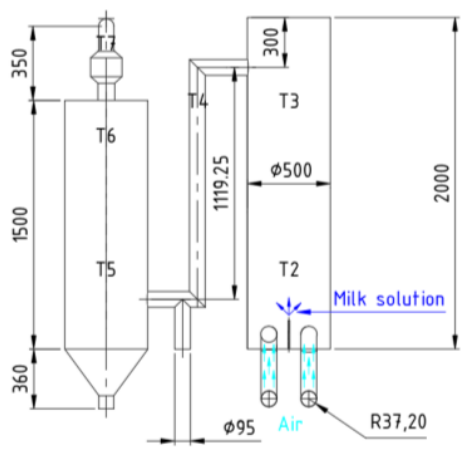

Figure 5 Spray Dryer in condition 3

\section{RESULTS AND DISCUSSION}

From the ANSYS Fluent Simulation Results on the Spray dryer, information is obtained that the flow in the first silo produces vortexes that occur in it.

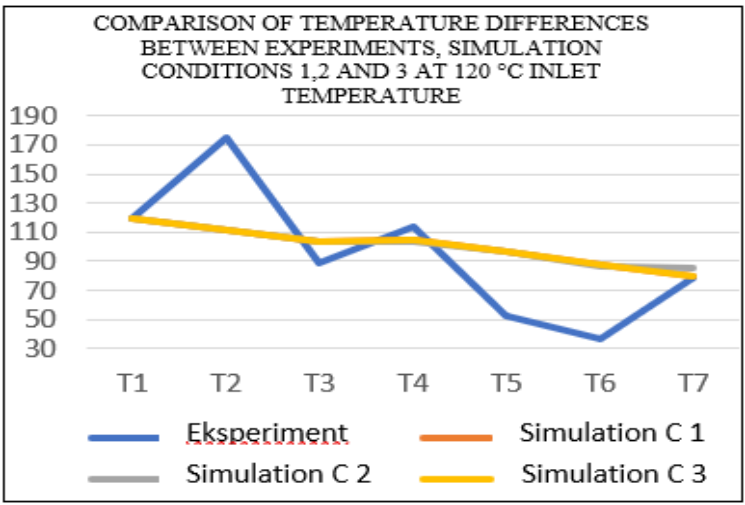

Figure 6 Graph of the temperature difference between experiments, simulated conditions 1,2,3 and 4

From figure 6 we found that experiment show almost same temperature as simulated. T3 is the thermocouple fixed in the first silo, when silo $1^{\text {st }}$ reached $200^{\circ} \mathrm{C}$, the 
milk injected so it will maintained the designated temperature, $120^{\circ} \mathrm{C}$.

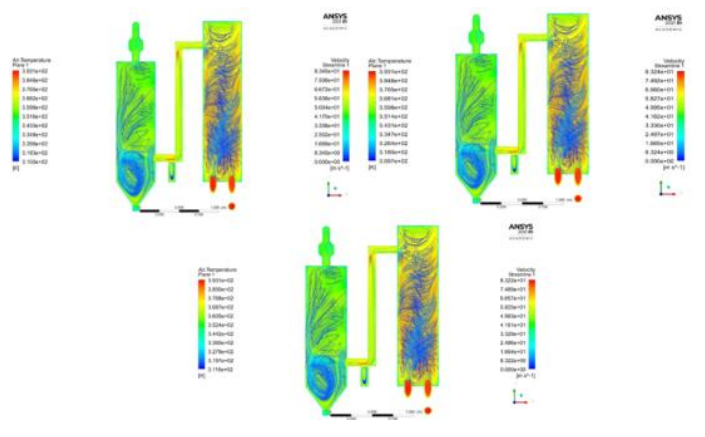

Figure 7 Temperature distribution and fluid path simulation results from Spray dryer conditions 1, 2 and 3 at 120 ${ }^{\circ} \mathrm{C}$ inlet

The flow of air velocity that occurs in the first silo is dominated by blue which means the velocity value is $8.2 \mathrm{~m} / \mathrm{s}$ to $24 \mathrm{~m} / \mathrm{s}$. The increase in air velocity is quite large in the flow pipe with a diameter of $95 \mathrm{~mm}$. Its speed changes 3 times greater than $25 \mathrm{~m} / \mathrm{s}$ to $83 \mathrm{~m} / \mathrm{s}$. This happens because of the narrowing in the form of changes in the large cross-sectional area to be small. Due to the change in cross-sectional area, the airflow slowly increases. For the simulation results of heat transfer that occurs in the Spray dryer, it is found that the first silo has a good heat distribution. Marked by an even yellow color around the first silo. This even temperature distribution caused by the vortex inside the silo. From 3 meditated condition, almostgiving the same fluid pattern of vortex. This gives us information that cross flow from the prime air inlet made huge vortex and high turbulencies. This made a great mixing of heat distribution along first silo.

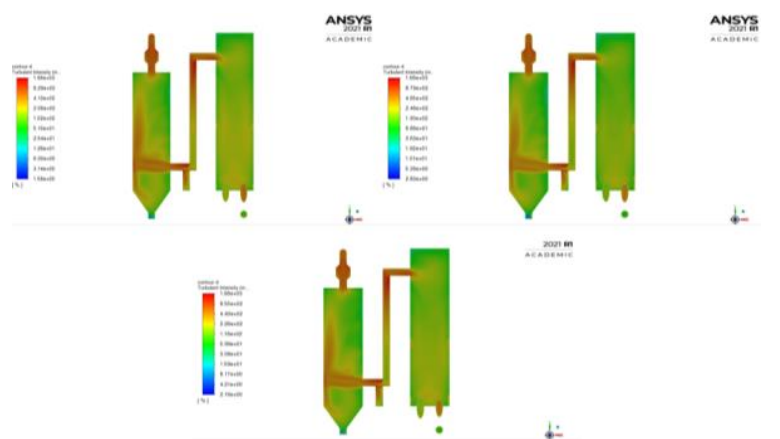

Figure 8 Intensity of turbulence under conditions 1, 2, and 3 with an inlet temperature of $120^{\circ} \mathrm{C}$

The turbulence intensity is found to be $188 \%$ for condition 2 and $174 \%$ for condition 3 . And $165 \%$ for condition 1 . High turbulency occurred in condition 2 caused by conjugation of flow started since the first time the air and milk spray comes out due to its spray projection $45^{\circ}$. The flow of milk collided with air and turns it direction and causing wake that mixed air layer. The turbulence region also start in early regime of flow and continuous to the end of silo, so it has larger turbulence regime. The first condition held least turbulence since there are some milk spray that blocked by air duct, but wider area of turbulence. In $3^{\text {rd }}$ condition, the collision regime is far away from the source, so it has smaller area for collision of milk spray and air, eventhough the intensity is quite high, but area of collision smaller compared to condition 2 .

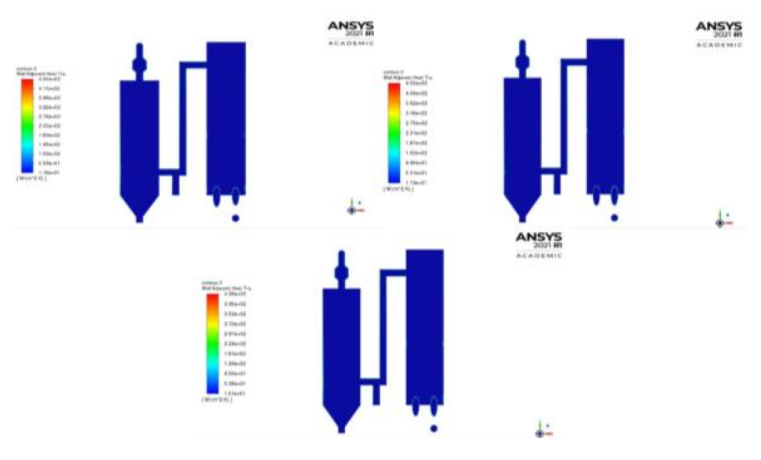

Figure 9 Heat Transfer Coefficient at conditions 1, 2 and 3 with an inlet temperature of $120^{\circ} \mathrm{C}$

The heat transfer coefficient decreases as the intake air temperature increases. The highest heat transfer coefficient value is in condition 1 of $58.8 \mathrm{~W} / \mathrm{mK}$ until it decreases to $53.7 \mathrm{~W} / \mathrm{m}^{2} \mathrm{k}$. Then followed by conditions 2 and 3 of $57.4-52.8 \mathrm{~W} / \mathrm{m}^{2} \mathrm{~K}$ and $57.2-52.8 \mathrm{~W} / \mathrm{m}^{2} \mathrm{~K}$. Slight differences of heat transfer coefficient happened, because the turbulence intensity difference is slight. This explain, how the effectiveness of vortex generator to distribute the heat

\section{CONCLUSION}

Based on the analysis of the CFD Spray dryer simulation results, it can be concluded as that the shape of the air flow in the first silo is dominantly rotating at the center of the silo, and the collision between the milk droplets and hot air happened on large area upwards the silo. This help the fluidization to happen faster and better. Inside the first silo there are turbulent flows caused by vortex generator only occurs inside the first silo. The area of turbulence varies between 3 conditions, but almost similar. Vortex flow changed to uniform flow when enters the transition pipe. If viewed from the heat distribution, conditions 1, 2 and 3 have good heat distribution. However, condition 2 has the better heat distribution than conditions 1 and 3. This is due to the highest turbulence 
intensity value and larger area of turbulence. But seeing the area of turbulence, condition 1 give the widestarea of turbulence.

\section{ACKNOWLEDGMENT}

I would like to thanks to Mrs Chairunnisa Rachmanindya that already dedicated her time to help me and the boys in collecting data. Thanks to Rizqi who did the simulation and Fajar who did the experiments and Yoga who validate the jobs from the two boys. Hopefully this research can contribute to the fluid research.

\section{REFERENCES}

[1] N. A. Mufarida, Perpindahan Panas \& Massa pada Spray Dryer. 2016.

[2] P. Setyadi, N. Yoga, and A. Luthfi, "Prosiding Seminar Nasional NCIET Vol.1 (2020) A22-A28 National Conference of Industry, Engineering and Technology 2020, Semarang, Indonesia.," vol. 1, pp. 22-28, 2020.

[3] S. Koswara, "Produksi : eBookPangan.com," pp. 127, 2009.

[4] M. Djaeni, A. Prasetyaningrum, and L. Belakang, "Sistem Pengering Adsorpsi Dengan Zeolite ( Parzel ) Untuk Produk Bahan Pangan Dan Tanaman Obat : Sebuah Terobosan Di Bidang," pp. 2007-2010, 2008.

[5] D. F. Fletcher, B. Guo, D. J. E. Harvie, T. A. G. Langrish, J. J. Nijdam, and J. Williams, "What is important in the simulation of spray dryer performance and how do current CFD models perform?," Appl. Math. Model., vol. 30, no. 11, pp. 1281-1292, 2006, doi: 10.1016/j.apm.2006.03.006.

[6] Y. Effendi, Syaiful, M. Djaeni, and S. H. Winoto, "The analysis of heat transfer and pressure loss for the air flow through heated cylinders with concave delta winglet vortex generators in rectangular channel: An experimental study," IOP Conf. Ser. Mater. Sci. Eng., vol. 673, no. 1, pp. 0-6, 2019, doi: 10.1088/1757-899X/673/1/012111.

[7] H. Alwan and Y. Bindar, "Flow pattern analysis on sticky regime and effectiveness of volume chamber for milk production using CFD method," IOP Conf. Ser. Mater. Sci. Eng., vol. 673, no. 1, pp. 0-9, 2019, doi: 10.1088/1757-899X/673/1/012019.

[8] P. D. P. Syafriyudin, "Oven Pengering Berbasis Mikrokontroler Atmega 8535 Menggunakan Pemanas Pada Industri Rumah Tangga," J. Teknol., vol. 2, no. 1, pp. 70-79, 2009, doi: 10.1002/9783527621095.

[9] Y. A. Cengel, "Heat Transference a Practical Approach," MacGraw-Hill, vol. 4, no. 9, p. 874,
2004, [Online]. Available: http://dx.doi.org/10.1007/978-3-642-20279-7_5.

[10] I. N. S. Winaya, "Teknik Fluidisasi," Univ. Udayana, p. 60, 2016.

[11] S. Maulana, Pemanfaatan Computational Fluid Dynamics (Cfd) Dalama Strategi Penelitian Simulasi Model Pada Teknologi Penghawaan Ruang, vol. 2, no. 2. 2016.

[12] a. Murrone and P. Villedieu, "Numerical modeling of dispersed two-phase flows," Aerosp. Lab, no. 2, pp. 1-13, 2011, [Online]. Available: http://www.aerospacelabjournal.org/sites/www.aerospacelabjournal.org/files/AL2-04.pdf.

[13] S. N. Saleh, "CFD Simulations of a $C$ o-current Spray Dryer," vol. 4, no. 2, pp. 226-231, 2010.

[14] A. B. Prasetiyo, A. A. Azmi, D. S. Pamuji, and R. Yaqin, "Pengaruh Perbedaan Mesh Terstruktur dan Mesh Tidak Terstruktur Pada Simulasi Sistem Pendinginan Mold Injeksi Produk Plastik," vol. 2018, no. November, pp. 400-406, 2018. 